\title{
STYLISTIC FEATURES OF RUSSIAN AND KAZAKHSTAN PRE-ELECTION POLITICAL SLOGANS
}

Tleulesova A. Sh., PhD Pedagogic sciences, Associate Professor, S. Seifullin Kazakh Agro Technical University, Nur-Sultan, Kazakhstan

Nugumanova A. N., Master of philological sciences, lecturer, S. Seifullin Kazakh Agro Technical University, Nur-Sultan, Kazakhstan

DOI: https://doi.org/10.31435/rsglobal_conf/25112020/7257

\begin{abstract}
Such a specific element of political communication as a slogan, which is often used within the election campaign, has been to the present day a less studied issue in the Russian and Kazakh political linguistics. Nowadays this genre of political text is being mainly mastered by the sociologists, politologists, image-makers, etc., dealing with the issues of electoral technologies. This article deals with the study of stylistic features of a political slogan which are characteristic for the election campaigns of Russia and Kazakhstan held in the period of recent decades. The results of the study show that the main purpose of their use is to enhance the expressiveness of the statement. This allows us to conclude that the language of political slogans has great opportunities and resources to implement this impact. It also becomes apparent that persuasiveness is one of the key functions of the slogan's pragmatic functions.
\end{abstract}

Keywords: political linguistics, slogan, election campaign, stylistic, lexis.

Введение. Сила воздействия на избирателей зависит от такого фактора, как запоминаемость информации. Для того, чтобы внушить определенную информацию избирателю, недостаточно просто ее сообщить. Вследствие этого определяется основная цель использования слогана - привлечение внимания к кандидату, ознакомление с программой баллотирующегося с целью получить голос при использовании кратких и максимально экспрессивных словосочетаний.

Вся совокупность прагматических характеристик слогана реализуется при помощи разнообразных выразительно-стилистических средств, направленных на усиление эмотивной и персуазивной функций. Коммуникативные способности политического слогана могут улучшиться при употреблении в его структуре выразительных средств языка, что помогают сделать слоган ярким и запоминающимся, привлекая внимание избирателей.

Во многих современных исследованиях дан обзор стилистических средств, которые часто используются в российской и казахстанской политической лингвистике. С точки зрения собственно лингвистики, в политической речи используются те же стилистические средства, которые встречаются и в других сферах коммуникации. Необходимо отметить, что, как и в других коммуникативных сферах, удачное использование стилистических фигур и тропов делает изложение более ярким, выразительным, привлекает внимание читателей и слушателей.

Цель исследования - выявить лингвостилистические приемы, нашедшие отражение в слоганах предвыборных кампаний

Методы исследования. Так как в лингвистической науке еще нет устоявшегося подхода классифицирования изобразительных средств, поэтому мы рассматриваем стилистические средства политических слоганов с учетом поуровневого принципа языковой системы.

Результаты исследования. Применение стилистических средств с целью придания персуазивного эффекта часто встречается в слоганах и не ограничивается только синтаксисом. Слоган привлекает внимание и запоминается человека, в первую очередь, благодаря своей яркой и образной лексике. Поэтому при создании персуазивного эффекта слоганов чаще всего участвуют именно лексические средства.

Говоря о лексическом ярусе, в первую очередь, необходимо сказать о метафоре. В последнее время, по мнению исследователей, она является «одним из сильных средств представления политических концепций и воздействия на политическое сознание общества» [26, с. 122]. Ученые стремятся определить функции политической метафоры, рассмотреть ее основные типы и модели, дать характеристику закономерностям развертывания метафорического образа в политическом тексте. 
Для эмоционально-психологического воздействия на избирателя, включая его в избирательный процесс, метафора должна иметь свойства быть несложной для понимания. Она должна помочь кандидату получить необходимый результат на заключительном этапе выборов, поэтому избиратель, на основе ассоциативно передаваемого образа, должен понимать поддерживает или не поддерживает баллотирующийся то, что метафора обозначает в реальности: «Силе разума - энергию молодости!» (Ш. Маратулы), «Выбери светлую сторону» (А. Гориславцев, 2016).

Благодаря обобщенности и образности метафоры, в слоганах стали использовать один из ее видов синекдоху: «Севастополь выбирает Комоедова!» (В. Комоедов, КПРФ, 2016), «Севастополю нужен Белик!» (Д. Белик, партия «Единая Россия», 2016). В данных слоганах имя собственное (Севастополь) является нам как совокупность однородных составляющих, значение слова становится шире, что приводит к обобщенному характеру высказывания. Синекдоха в данном примере определяет и семантико-синтаксическую организацию слогана: приближенный к роли подлежащего «несубъектный» актант дает возможность воздержаться от прямого призыва отдать голос за необходимого кандидата. Стилистический прием, заключающийся в наделении субъекту действия свойств, которые предписаны человеку, позволяет нам относить данный троп к одному из видов аллегории.

В предвыборных политических слоганах также реализуется тактика субъектной идентификации: кандидат позиционирует себя как носителя той единственной идеологии, которая призвана улучшить жизнь избирателей. Исключительность политической позиции в этом плане отображается через использование гиперболы: «Пока другие только говорят, мы уже делаем. Лучше - с нами!» (ЛДПР), «Нама сила - в правде!» (Коммунистическая партия Российской Федерации).

В политической рекламе особое внимание уделяется иронии, которая должна дискредитировать или настроить избирателей против соперников кандидата или партии. Подобный прием чаще всего применяется во время накаляющейся предвыборной гонки: «Только ЛДПР или терпи дальше!» (ЛДПР, 2009).

В слоганах встречается такой стилистический прием, как аллюзия. Некоторые кандидаты с «говорящей» фамилией, делают акцент именно на ней, подчеркивая внимание на общеизвестности своей фамилии: «Тем, кто ложится спать, спокойного сна! Цой жив! (Ю. Цой, 2017), другие стараются выделить свои личностные качества: «Мне нужен Ваш голос, чтобы обеспечить честные выборы и защищать законные права граждан, а Вам нужен честный депутат» (Р. Честных, 2016), «Квачкова - наша Надежда!» (Н. Квачкова, 2008).

Одним из самых применяемых в политическом тексте приемов является эпитет, способный подчеркнуто дать характеристику предмету речи. Эта способность и объясняет его частое использование в политических слоганах. Отличаясь от логического определения, которое по обыкновению выделяет данный предмет из многих, эпитет в своем случае может подчеркнуть в слогане одно из свойств предмета речи: «Энергия перемен, энергия обновления» (В. Шумков, 2019) или переносить на него свойства другого предмета: «Железное слово железное дело» (А. Терентьев, 2016).

Эпитет в структуре слоганов исполняют свою главную функцию: в образной форме отображают индивидуальные черты баллотирующихся, позволяющие им выгодно себя позиционировать на фоне противников.

Одним из речевых явлений, используемым в политическом тексте, является эллипсис: «Нефть - народу! Коррупиионеров - в тюрьму! «Адилет» - в парламент!» (партия «Адилет», 2012), «Главное - Москва! Главные - москвичи!» (Ю. Собянин, 2013), «Природное богатство страны - на службу простым людям!» (партия «Справедливая Россия», 2011).

В таких конструкциях эллипсис первоначально необходим - одна из частей слоганов намеренно опускается с целью придать тексту динамичность. Данный способ придает речевую или психологическую характеристику кандидата. Помимо этого, эллипсис сокращает структуру слогана и помогает ему соответствовать внешним параметрам.

Еще одним приемом, позволяющим сделать политический слоган более динамичным, является париелляиия: «Жириновский. Или будет хуже» (В. Жириновский, 2012), «Надежныгй. Русский. Свой» (А. Павлов, 2016). В большинстве политических текстов парцеллированные конструкции широко функционируют в сочетании с другими стилистико-синтаксическими 
средствами языка. Используемые как важный источник экспрессии речи, парцеллированные конструкции дают возможность актуализировать, выделить с определенной целью какую-то часть высказывания. Помимо этого, в их сжатой форме дается больший объем информации, что также нужно учитывать в слогане.

Одним из стилистических приемов, применяющихся на синтаксическом уровне слогана, является антитеза. В большинстве случаев, основой ее на лексическом уровне является антонимия, а на синтаксическом - параллелизм конструкций.

В данном случае сравниваются противоположные, но соотносительные понятия: «У власти - сила, у нас - правда» (КНПК, 2012), «Власть для москвичей, а не москвичи для власти!» (КПРФ, 2009), «Диденко за нас. Mbl за Диденко» (ЛДПР, 2017). Чаще всего встречаются антонимы, описывающие деловые качества баллотирующегося: «Я не считаю ваши голоса - я их сльшщу!» (В. Жириновский, 2011), «Сибиряки не обещают. Они делают» (С. Жвачкин, партия «Единая Россия», 2017). Такое стилистическое средство дает возможность выделить высказываемую мысль, укрепляя ее эмоционально-психологическое влияние на создание у избирателя необходимого мнения о кандидате и его предвыборной программе.

В рассматриваемых нами слоганах применяется и такие приемы, как повторы, анафоры и эпифоры: «ЗА Александра Хлопонина. ЗАнятость, ЗАрплата, ЗАконность, ЗАбота» (А. Хлопонин. 2001), «Одна страна! Одна судьба! Один лидер!» (партия «Нур Отан»).

Для более эффективного запоминания предвыборной программы и ее основных положений кандидаты используют прием повторения одного ключевого слова, группы слов или целых предложений. Этот прием дает возможность сделать акцент на самом важном и придать политическому тексту динамику и ритм. Это отличный способ «выделиться из толпы» и внедрить «ключевое слово» (например, имя кандидата или партии) в сознание избирателей.

В структуре политического слогана встречается и такой стилистический прием, как сравнение: "С сибирским характером / Я сибирской породы, / Ел я хлеб с черемшой, / И мальчишкой паромы / Я таскал, как большой» («Партия сибирской породы», 2013), «Такие, как Тимошков, проверены временем» (Ю. Тимошков, 2001). Выводимое на основе категорий «равенства - неравенства», большей или меньшей степени качества сравнение может выражаться как в грамматической категории степеней сравнения прилагательных и наречий, а также в лексике и фразеологии. Образная трансформация слогана обуславливается тем, что сопоставляются разноплановые понятия, включаемых союзом как, именно поэтому основой стилистической выразительности слогана лежит синтаксическое сопоставление.

Употребление слоганов со сравнением носит скорее не императивный, а упреждающий характер: избиратель, имея свои внутренние ожидания и установки, должен решить перед окончательным выбором, кто из баллотирующихся превосходит эти ожидания или не соответствует им.

Каждый кандидат хочет иметь слоган, уникальный от остальных. Чтобы сделать его максимально выразительным, авторы нередко применяют клишированные конструкции.

В публицистических текстах, как показывает практика, клишированные конструкции большей частью содержат в себе иронический смысл, в политических текстах они чаще выражают жизнеутверждающее начало. «Сила в правде!» (В. Комоедов, КПРФ, 2016), «Жириновский - пророк в своем Отечестве» (ЛДПР, 2017), «За тех, кому на Руси жить нелегко» (Д. Поташев, 2016), «Приеду, увижу, посажу» (ЛДПР, 2010).

Как правило, чтобы избиратель правильно воспринял такие конструкции и кандидат смог бы установить с ним контакт, необходимо иметь избирателю фоновые знания о написанном в слогане. Если ему цитируемый источник неизвестен, маловероятно, что кандидат сможет установить доверительное общение между ним и избирателем: «Я не хочу победы любой иеной, я никому не хочу ставить ногу на грудь. Кандидат в депутаты из ЮжноСахалинска Юрий Цой за честные выборы!» (Ю. Цой, 2012). Слоган, безусловно, отражает внутренний мир кандидата, его ценности и установки, но для избирателя, незнакомого с творчеством Виктора Цоя и рок-группы «Кино», данный слоган вряд ли будет понятен.

Следовательно, автор при использовании в слогане высказывания или цитаты, должен применять те тексты, которые имеют значение для отдельного избирателя (личности) в познавательном и эмоциональном плане, обращение к которым «возобновлялось неоднократно в дискурсе данной языковой личности» [69, с. 216-237]. 
Удачный и запоминающийся слоган в процессе коммуникации сам может стать прецедентным текстом, который, по мнению Е.Н. Копейкиной, содержит себе «общие черты с прецедентными текстами других жанров, такие как: 1) побудительность; 2) популярность; 3) риторичность и повторяемость; 4) непереводимость; 5) анонимность (адресата и адресанта); 6) сигнальность и перспективность; 7) номинативность; 8) обобщенность; 9) лаконичность, броскость, убедительность» [70, с. 63]. Небольшой комментарий нужен для требования «анонимности адресата и адресанта»: он не соответствует правилам политической коммуникации, не считая случаи методов «черного пиара», когда заказчик обличительного текста желает сохранить свою анонимность.

Слоганы предвыборных компаний регионального уровня только в редких случаях выходят на уровень прецедентных текстов. В их разряд попадают слоганы предвыборных кампаний самого высокого уровня: «Казахстан - наш общий дом. Казахстан - наша крепость. Нурсултан Назарбаев - наш Лидер», «План Путина - победа России» (2007). Такие слоганы в дальнейшем широко цитируются общественными деятелями, журналистами, политиками и т.д.

Выводы. Проведенный анализ стилистических средств в слоганах избирательных кампаний на материале российских и казахстанских СМИ показал нам, что основной целью их использование является на усиление экспрессивности высказывания. Это позволяет нам сделать вывод, что язык политических слоганов имеет большие возможности воздействия и ресурсы для осуществления данного воздействия. Также становится очевидным то, что персуазивность является одной из ключевых прагматических характеристик слогана, вследствие чего все стилистические особенности слогана так или иначе связаны с созданием персуазивного эффекта.

\section{REFERENCES}

1. Чудинов А.П. Политическая лингвистика. - М.: Наука, 2008. - 254 с.

2. Караулов, Ю.Н. Русский язык и языковая личность. - М.: Наука, 1987. - 264 с.

3. Копейкина Н.Е. Коммуникативно-прагматический аспект экспрессивности институционального рекламного слогана: Дис. ... канд. филол. наук. - М., 2004. - 200 с. 